\title{
PENGARUH PEMBERIAN KOMPENSASI TERHADAP PRESTASI KERJA GURU DAN KARYAWAN DI SMA DR. SOETOMO SURABAYA
}

\author{
Nurus Safa'atillah *) \\ ${ }^{*}$ Prodi Manajemen Fakultas Ekonomi Universitas Islam Lamongan, \\ E-mail: Nurus_safaatillah@yahoo.com
}

\begin{abstract}
ABSTRAK
Penelitian ini bertujuan untuk mengetahui pengaruh pemberiann kompensasi terhadap prestasi kerja guuru dan karyawan di SMA Dr.Soetomo Surabaya. responden yang terlibat dalam penelitian ini sebanyak 100 orang. metode yang digunakan adalah sampel populasi. pengumpulan data dilakukan dengan menyebar angket. metode analisis data dilakukan dengan regresi linier berganda menggunakan software spss. hasil uji regresi menunjukkan bahwa variabel pemberian kompensasi berpengaruh besar terhadap prestasi kerja guru dan karyawan di SMA Dr.Soetomo Sorabaya.berdasarkan hasil penelitian tersebut dapat disimpulkan bahwa pemberian kompensasi berpengaruh positif terhadap prestasi kerja guru dan karyawan di SMA Dr.Soetomo Surabaya
\end{abstract}

\section{Kata kunci :Kompensasi(X), Prestasi Kerja Guru dan Karyawan (Y)}

\section{PENDAHULUAN}

Prestasi kerja pengajar dan karyawan dari suatu lembaga pendidikan, selalu menekankan pelaksanaan tugas pengajar dan ketuntasan tugas tata usaha,keuangan dan bagian kebersihan sedangkan tugas-tugas yang harus dilaksanakan adalah bagian dari pekerjaan atau posisi dalam lembaga pendidikan.

Para pimpinan lembaga pendidikan secara rutin menilai keefektifan individu melalui proses evaluasi prestasi kerja, evaluasi prestasi kerja ini menjadi dasar untuk kenaikan gaji, promosi, insentif, kompensasi dan jenis imbalan lain yang diberikan lembaga bimbingan belajar itu. Menurut situasi yang lazim setiap individu bekerja dalam kelompok unit kerja, dalam beberapa hal keefektifan kelompok adalah jumlah sumbangan dari seluruh anggautanya, dalam hal lain keefektifan kelompok unit kerja melebihi jumlah sumbangan individual. Karena organisasi terdiri dari individu dan kelompok unit kerja, keefektifan organisasi adalah fungsi dari keefektifan individu dan kelompok unit kerja, walaupun demikian keefektifan organisasi melebihi jumlah keefektifan individu dan kelompok unit kerja. Prestasi kerja individu menjadi bagian dari prestasi kerja kelompok unit kerja, yang pada gilirannya menjadi bagian dari prestasi kerja organisasi lembaga pendidikan. Di dalam lembaga pendidikan yang efektif, manajemen membantu prestasi kerja secara keseluruhan, yaitu suatu keseluruhan yang lebih besar dari sekedar penjumlahan kelompok-kelompok unit kerja. Tidak ada suatu ukuran atau kriteria yang memadai, yang dapat mencerminkan prestasi kerja lembaga pendidikan. Prestasi kerja lembaga pendidikan harus dilihat dalam hubungan ukuran berganda di dalam suatu kerangka. Tetapi ketidak efektifan prestasi kerja sesuatu tingkatan organisasi lembaga pendidikan merupakan pertanda bagi manajemen untuk mengambil tindakan korektif. Semua tindakan korektif manajemen akan berpusat pada elemen perilaku organisasi lembaga pendidikan, struktur, dan proses.

Jadi keefektifan kelompok unit kerja lebih besar dibandingkan dengan jumlah keefektifan individual karena perolehan terwujud melalui usaha gabungan individual dan kelompok unit kerja. Tugas manajemen adalah mengindentifikasi sebab-sebab keefektifan organisasi lembaga pendidikan, kelompok unit kerja dan individu.

Dengan meningkatnya kemajuan teknologi mengakibatkan semakin berkembangnya pemahaman manusia tentang pentingnya aspek sumber daya manusia dalam suatu organisasi lembaga pendidikan. Bagaimanapun tingginya teknologi tanpa didukung oleh manusia sebagai pelaksana operasionalnya, tidak akan mampu 
menghasilkan suatu output yang sesuai dengan tingkat efisiensi yang tinggi. Betapapun modernnya mesin-mesin yang digunakan, unsur manusia masih akan tetap memegang peranan yang sangat menentukan. Oleh karena itu pemahaman dan pengembangan sumber daya manusia didalam suatu organisasi lembaga pendidikan menjadi sangat penting. Dalam kehidupan modern dewasa ini, faktor manusia sangatlah diutamakan dengan menitikberatkan secara mendasar pada pengukuran hasil nyata yang mampu dicapai oleh seorang tenaga kerja yang terlibat dalam proses penentuan sasaran. Prestasi kerja didalam organisasi lembaga pendidikan diukur dari mampu tidaknya mewujudkan sasaran yang telah diterapkan sebelumnya dan bila mampu jauh hasil nyatanya dibandingkan dengan sasaran tersebut. Ketidak jelasan dalam menetapkan sasaran, akan mengakibatkan tenaga kerja tidak dapat mengevaluasi dan tidak mengetahui sampai sejauh mana prestasi kerja yang telah dicapainya.

\section{TINJAUAN PUSTAKA \\ Kompensasi}

Kompensasi ini dirumuskan sebagai balas jasa yang memadai dan layak kepada karyawan untuk sumbangan mereka kepada tujuan organisasi. Kompensasi (compensation) menurut Ishak Arep dan Hendri Tanjung (2002:197), adalah : segala sesuatu yang diterima oleh karyawan sebagai balas jasa atas upaya-upaya yang telah diberikan kepada perusahaan.Ini penting dilakukan karena merupakan faktor yang mendorong partisipasi karyawan pada perusahaan dan disamping itu merupakan hak karyawan karena telah menyumbangkan tenaga dan pikirannya demi kemajuan dan perkembangan perusahaan. Dalam hal ini kompensasi diberikan harus bijaksana sesuai dengan tugas dan tanggung jawab karyawan yang bersangkutan.

Walapun beberapa Penulisan tentang moral yang dilakukan akhir-akhir ini cenderung mengurangi pentingnya arti penghasilan dalam bentuk uang bagi karyawan, namun kita tetap berpendapat bahwa kompensasi adalah salah satu fungsi manajemen sumberdaya manusia yang sangat penting. Sedangkan metodametoda kempensasi yang dapat digunakan untuk meningkatkan prestasi kerja dibagi dalam empat kategori yaitu :
- Perbaikan-perbaikan produk dan proses.

- Perbaikan-perbaikan pekerjaan.

- Motivasi karyawan.

- Perubahan Organisasional.

- Tujuan Pemberian Kompensasi

Salah satu tujuan seseorang menjadi karyawan adalah karena adanya kompensasi. Dengan kompensasi yang diterimanya ini karyawan berharap dapat memenuhi kebutuhannya. Oleh karena itu setiap perusahaan dalam menetapkan besarnya kompensasi kepada para karyawannya harus diusahakan sedemikian rupa sehingga kompensasi kepada para karyawannya harus diusahakan sedemikian rupa sehingga kompensasi terendah yang diberikan dapat memenuhi kebutuhan mereka secara minimal.

Berikut ini penulis akan mengemukakan pendapat dari Malayu S.P. Hasibuan (1994:137), mengenai tujuan pemberian kompensasi, antara lain :

- Ikatan Kerja sama

- Kepuasan kerja

- Pengadaan efektif

- Motivasi

- Stabilitas karyawan

- Disiplin

- Pengaruh Serikat Buruh

- Pengaruh pemerintah

Banyaknya faktor yang mempengaruhi dalam penentuan besarnya kompensasi yang diberikan perusahaan kepada karyawannya, penulis mencoba mengetengahkan pendapat beberapa ahli.

Flippo dengan alih bahasa Mas'ud (1994:4), mengemukakan faktor-faktor penting yang mempengaruhi kabijakan kompensasi antara lain :

- Permintaan dan penawaran

- Serikat-serikat buruh

- Kemampuan untuk membayar

- Biaya hidup

- Pemerintah

\section{Metode Pemberian Kompensasi}

Biaya tenaga kerja merupakan sumbangan tenaga manusia pada produksi dan merupakan faktor biaya penting yang perlu diukur, dikendalikan dan dianalisis secara terus- 
menerus. Biaya tenaga kerja terdiri dari gaji pokok dan tunjangan-tunjangan.

- Tarif Dasar

- Tunjangan-tunjangan

- Upah Insentif

- Bonus Perorangan

- Bonus Kelompok

\section{Prestasi Kerja}

Salah satu tujuan pengelolaan tenaga kerja adalah meningkatkan prestasi kerja pada suatu organisasi. Faktor prestasi kerja tersebut merupakan hal yang akan menentukan kelangsungan hidup suatu organisasi atau perusahaan. Dengan tingkat prestasi kerja yang tinggi, tentunya perusahaan akan memperoleh laba yang cukup tinggi juga.

Program prestasi kerja merupakan suatu progam yang harus dilaksanakan oleh setiap organisasi perusahaan ataupun instansi pemerintah. Untuk mendapatkan karyawan perlu diadakannya program prestasi kerja yang diharapkan nantinya dapat meningkatkan kompensasi bagi pegawai yang bersangkutan.

\section{Penilaian Prestasi Kerja}

Untuk meningkatkan prestasi kerja, penilaian yang dilakukan oleh perusahaan atau organisasi harus didasarkan atas tujuan yang ditetapkan oleh perusahaan atau organisasi. Kemudian perusahaan atau organisasi itu sendiri mengadakan penilaian dari kemampuan dan minat seorang karyawan, kemampuan dan penerimaan atas penjelasan delegasi tugas dan peran, serta tingkat motivasi seorang karyawan.

Dari hasil penilaian prestasi kerja dapat diketahui berapa besar potensi karyawan dalam bekerja serta mengetahui kelebihan dan kekurangan para karyawan yang dinilai. Hasil dari penilaian tersebut dapat menentukan kebijaksanaan dalam menetapkan tindakan dan keputusan yang dilakukan oleh pimpinan perusahaan atau organisasi.

Pada dasarnya prestasi kerja merupakan suatu sikap dan falsafah hidup dimana seseorang memandang bahwa kehidupan hari ini lebih baik dari hari-hari kemarin, dan kehidupan besok harus lebih baik dari hari ini. Dengan falsafah hidup seperti ini, seseorang akan terdorong untuk tidak cepat merasa puas terhadap hasil- hasil yang telah dicapai, sehingga ia akan terus berusaha untuk meningkatkan kemauan dan kemampuan kerjanya.

Dari pengertian di atas maka dapat diambil suatu kesimpulan yaitu :

- Dalam penilaian prestasi harus seefektif mungkin.

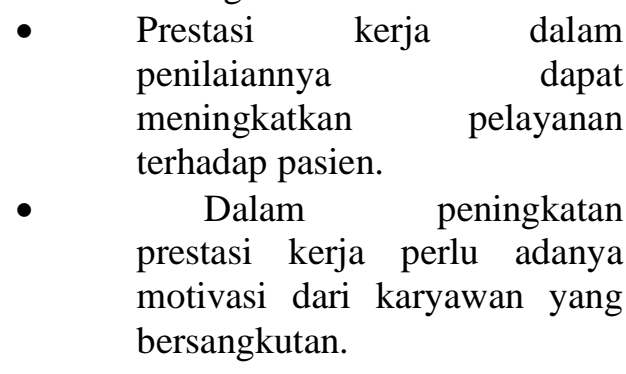

\section{Faktor-faktor Yang Mempengaruhi Prestasi Kerja}

Menurut Payman J. Simanjuntak (1985:30), prestasi kerja karyawan perusahaan akan dipengaruhi oleh ketiga faktor berikut :

- Kualitas dan kemampuan kerja karyawan

- Sarana Pendukung

Sarana pendukung bagi peningkatan prestasi/produktivita kerja karyawan ini dapat dikelompokkan ke dalam dua golongan yaitu :

- Menyangkut lingkungan kerja, temasuk teknologi dan pelayanan, sarana dan peralatan yang digunakan, tingkat kesehatan kerja, serta suasana dalam lingkungan kerja itu sendiri.

- Menyangkut kesejahteraan karyawan, yang tercermin dalam sistem pengupahan dan jaminan sosial, serta jaminan bagi kelangsungan kerja karyawan.

- Supra Sarana

Menyangkut pentediaan sarana dan prasarana seperti peralatan dan mesinmesin produksi.

\section{- METODE PENELITIAN}

Setelah mengetahui masing-masing skor hasil Penulisan maka penulis akan mengadakan analisis statistik, untuk mengetahui tingkat hubungan antara pemberian kompensasi (X) dengan prestasi kerja guru dan karyawan (Y).

- PEMBAHASAN HIPOTESIS 
- Pengaruh pemberian kompensasi terhadap prestasi kerja guru dan karyawan

Bila variabel $x$ dan $y$ dikorelasikan, titik-titik koordinat yang terdapat dalam diagram pencar akan bertendensi membentuk suatu garis linier, lihat hasil tabel-tabel aplikasi statistik dengan SPSS 11.00 for windows di bawah ini.

TABEL 6

DESCRIPTIVE STATISTICS

\begin{tabular}{|l|c|c|c|}
\hline \multicolumn{1}{|c|}{ VARIABLE } & MEAN & STD. DEVIASI & $\mathrm{N}$ \\
\hline PEMBERIAN KOMPENSASI & 33,5250 & 2,01977 & 40 \\
PRESTASI KERJA GURU & 34,1500 & 2,21866 & 40 \\
\hline
\end{tabular}

Tabel 6 memperlihatkan deskripsi semua variabel yang diregresikan. yakni variabel Y (PRESTASI KERJA GURU) sebagai variabel "dependent" dan variabel $X$ (PEMBERIAN KOMPENSASI) sebagai "independent".

Isi deskripsi tersebut adalah ; jumlah kasus (n), rata-rata (means), dan standar deviasi.
Pada tabel 6, variabel PEMBERIAN KOMPENSASI memiliki nilai rata-rata (mean) 33,5250, standard deviasi 2,01977 dan jumlah kasus ada 40. Variabel PRESTASI KERJA GURU memiliki nilai rata-rata (mean) 34,1500, standard deviasi 2,21866 dan jumlah kasus ada 40 .

TABEL 7

CORRELATIONS

\begin{tabular}{|l|c|c|}
\hline \multicolumn{1}{|c|}{ VARIABLE } & $\begin{array}{c}\text { PRESTASI KERJA } \\
\text { GURU } \\
\text { PEARSON CORRELATION }\end{array}$ & $\begin{array}{c}\text { PEMBERIAN } \\
\text { KOMPENSASI } \\
\text { X }\end{array}$ \\
-PRESTASI KERJA GURU (Y) & 1,000 & 0,972 \\
-PEMBERIAN KOMPENSASI (X) & 0,972 & 1,000 \\
\hline SIG (2-TAILED) & & 0,000 \\
-PRESTASI KERJA GURU (Y) & , &, \\
-PEMBERIAN KOMPENSASI (X) & 0,000 & 40 \\
N & 40 & 40 \\
-PRESTASI KERJA GURU (Y) & 40 & \\
-PEMBERIAN KOMPENSASI (X) & & \\
\hline
\end{tabular}

Tabel 7 menunjukkan hasil koefisien korelasi untuk semua variabel. Kita dapat membaca hasil korelasi tersebut baik dari samping (baris) maupun dari atas (kolom). Koefisien korelasi antara PEMBERIAN KOMPENSASI (X) terhadap PRESTASI $\operatorname{KERJA}$ GURU $(\mathrm{Y})=0,972$ dengan tingkat signifikansi $=0,000$. Jika memperhatikan angka $\mathrm{r}$ yakni 0,972 dan tingkat signifikansi 0,000 , maka keadaan ini menunjukkan adanya korelasi positif sangat kuat dan sangat signifikans.

Tingkat signifikan koefisien korelasi satu sisi dari output (diukur dari probabilitas) menghasilkan angka jauh di bawah 0,05, maka korelasi antara variabel PRESTASI KERJA GURU dengan PEMBERIAN KOMPENSASI sangat nyata 
TABEL 8

MODEL SUMMARY

DEPENDENT VARIABLE: PRESTASI KERJA GURU

\begin{tabular}{|c|c|c|c|c|}
\hline MODEL & $\mathrm{R}$ & $\mathrm{R}$ SQUARE & $\begin{array}{c}\text { ADJUSTED } \\
\text { R SQUARE }\end{array}$ & $\begin{array}{c}\text { STD. ERROR } \\
\text { OF THE ESTIMATE }\end{array}$ \\
\hline 1 & $0,972 \mathrm{a})$ & 0,945 & 0,943 & 0,48191 \\
\hline
\end{tabular}

a) Predictors: (Constant), PEMBERIAN KOMPENSASI

Pada bagian ini ditampilkan nilai $\mathrm{R}, \mathrm{R}$ Square, Adjusted R Square dan Std. Error. Dimana nilai R Square yang menunjukkan variabel bebas $\mathrm{X}$ (PEMBERIAN KOMPENSASI) terhadap Y (PRESTASI KERJA GURU) adalah sebesar 0,945. R Square yang digunakan di sini adalah $R$ Square yang disesuaikan (Adjusted $\mathrm{R}$
Square) yang merupakan indeks determinasi (\% pengaruh).

Pada model diatas, dimana variabel bebas $\mathrm{X}$ (PEMBERIAN KOMPENSASI) dimasukkan, maka didapat adjusted $r$ square sebesar 0,943 . Hal ini menunjukkan bahwa variabel PRESTASI KERJA GURU dipengaruhi variabel PEMBERIAN KOMPENSASI sebesar $94,3 \%$, sisanya $5,7 \%$ dipengaruhi oleh faktor lain

TABEL 9

ANALYSIS OF VARIANCE (ANOVA)

DEPENDENT VARIABLE: PRESTASI KERJA GURU

\begin{tabular}{|l|l|l|l|c|c|}
\hline \multicolumn{1}{|c|}{ MODEL } & SUM OF SQUARES & df & MEAN SQUARE & F & Sig. \\
\hline 1 REGRESSION & 150,275 & 1 & 150,275 & 647,068 & 0,000 a) \\
RESIDUAL & 8,825 & 38 & 0,232 & & \\
TOTAL & 159,100 & 39 & & & \\
\hline
\end{tabular}

a) Predictors: (Constant), PEMBERIAN KOMPENSASI

Pada hasil anova di atas ditunjukkan hasil $\mathrm{f}$ test model tersebut. Pada model akan tampak:

COEFFICIENTS

DEPENDENT VARIABLE: PRESTASI KERJA GURU

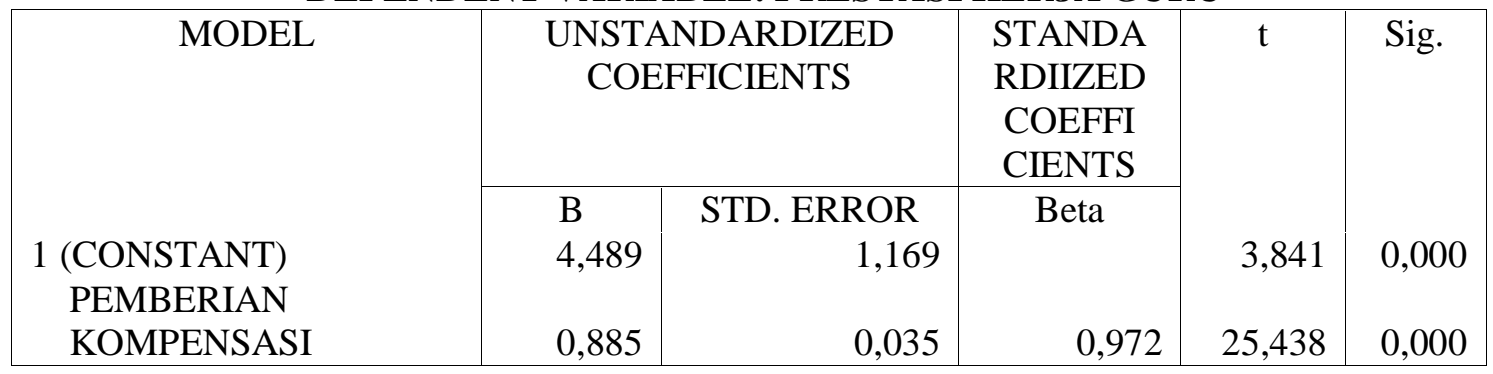

Pada bagian ini dikemukakan nilai koefisien a dan $b$ serta harga t-hitung serta tingkat signifikan. Persamaan model diatas :

$$
\mathrm{Y}=4,489+0,885 \mathrm{X}
$$

Pengertian persamaan model diatas :

$$
\mathrm{Y}=\text { PRESTASI KERJA GURU }
$$

$\mathrm{X}=$ PEMBERIAN KOMPENSASI

Nilai 4,489 merupakan nilai konstanta (a) yang menunjukkan bahwa jika tidak ada PEMBERIAN KOMPENSASI, maka tingkat
PRESTASI KERJA GURU akan mencapai 4,489 .

Sedangkan nilai $\mathrm{X}$ merupakan koefisien regresi, yang menunjukkan bahwa setiap adanya upaya penambahan PEMBERIAN KOMPENSASI sebesar 1 maka akan ada kenaikan PRESTASI KERJA GURU sebesar 0,885. Angka 0,972 pada standardized coeficients (beta) menunjukkan tingkat korelasi antara PEMBERIAN 
KOMPENSASI dan PRESTASI KERJA GURU.

Sedang nilai t merupakan nilai yang berguna untuk pengujian, apakah pengaruh PEMBERIAN KOMPENSASI (X) terhadap PRESTASI KERJA GURU (Y) benar-benar signifikans atau tidak.

Proses pengujian $t$ adalah sebagai berikut :

- Hipotesis :

Ho : koefisien regresi tidak signifikan

Ha : koefisien regresi adalah signifikan

- Ketentuan : (berdasarkan nilai t)

Jika thitung $>\mathrm{t}$ tabel $0,05(\mathrm{dk}=\mathrm{n}-2)$, maka ho : ditolak.

Jika thitung < t tabel 0,05 $(\mathrm{dk}=\mathrm{n}-2)$, maka ha : diterima.

- Kesimpulan :

Dari tabel di atas didapat harga $\mathrm{t}$ hitung sebesar 25,438. sedang harga t tabel dengan $\mathrm{dk}$ $(40-2=38)$ adalah 3,182 . jadi $t$ hitung $25,438>\mathrm{t}$ tabel $0,05(\mathrm{dk} 3)=3,182$. dengan demikian ho : ditolak dan ha : diterima. Dapat ditarik kesimpulan bahwa memang terdapat pengaruh yang signifikan antara PEMBERIAN KOMPENSASI (X) dengan PRESTASI KERJA GURU (Y).Untuk pengujian ini dapat pula dilihat melalui nilai signifikasi, dimana kita lihat bahwa nilai signifikasi adalah 0,000. Mengingat 0,000 adalah $<0,05$, maka dapat disimpulkan bahwa tingkat signifikasi sangat tinggi bahkan masih di bawah 0,01 (tingkat kepercayaan 99\%).

\section{KESIMPULAN}

Berdasarkan hasil dan pembahasan mengenai analisa pengaruh pemberian kompensasi terhadap prestasi kerja guru SMA Dr. SOETOMO SURABAYA, maka dapat diambil beberapa kesimpulan sebagai berikut :

- Persamaan regresi adalah $\mathrm{Y}=4,489+$ $0,885 \mathrm{X}$ berarti :

- Konstanta sebesar 4,489 menyatakan bahwa jika tidak ada pemberian kompensasi, maka prestasi kerja guru SMK YKTB 2 Surabaya adalah 4,489.

- Koefisien regresi X sebesar 0,885 menyatakan bahwa setiap usaha peningkatan pemberian kompensasi sebesar 1, maka prestasi kerja guru SMA Dr. SOETOMO SURABAYA akan naik sebesar 0,885 .
- Besar hubungan antar variabel pemberian kompensasi dengan variabel prestasi kerja guru SMK YKTB 2 Surabaya sebesar $r=$ 0,972. Hal ini menunjukkan variabel pemberian kompensasi mempunyai korelasi yang kuat terhadap peningkatan prestasi kerja guru SMA Dr. SOETOMO SURABAYA.

- $\quad$ Adjusted r square sebesar 0,943. Hal ini menunjukkan bahwa variabel prestasi kerja guru dipengaruhi variabel pemberian kompensasi sebesar $94,3 \%$, sisanya 5,7 $\%$ dipengaruhi oleh faktor lain.

\section{SARAN}

Berdasarkan pembahasan dan analisis data yang dilakukan dalam penelitian ini dapat disarankan beberapa hal antara lain :

- Evaluasi prestasi kerja harus mencakup keseluruhan periode pelaksana kerja, bukan hanya prestasi kerja yang ditunjukkan pada waktu akan dilakukan penilaian.

- Evaluasi prestasi kerja hendaknya dilakukan secara rasional sehingga hasilnya dapat diterima oleh manajemen, atasan dan staf pengajar

\section{DAFTAR PUSTAKA}

...., Pedoman Penulisan Sekolah Tinggi Ilmu Ekonomi Gotong Royong, Jakarta, 2007.

Flippo, Edwin B, Manajemen Personalia, Jilid I, Edisi ke tujuh, Alih Bahasa Moh. Masud, Penerbit Airlangga, Jakarta, 1994.

Hamalik, Oemar, Pendidikan Guru : Konsep Kurikulum, Strategi, Pustaka Martianana, Bandung, 1995.

Ibrahim, Rusli, Pengembangan Inovasi Kerikulum, Depdikbud, Jakarta, 2000.

Kumorotomo, Wahyudi, Etika Administrasi Negara, PT. Raja Grafindo Persada, Jakarta, 1992.

Manullang, M., Manajemen Personalia, Cetakan kesebelas, Penerbit Ghalia Indonesia, Jakarta, 1985.

Martoyo, Susilo, Manajemen Sumber Daya Manusia, Penerbit BPFE, Yogjakarta, 1987.

Moekijat, Manajemen Kepegawaian, Penerbit Alumni, Bandung, 1989. 
Proctor, John H. dan William Thorton, Manajemen Kepegawaian, terjemahan Moekijat Penerbit Alumni, Bandung, 1989.

Purwadarminta, WJS., Kamus Umum Bahasa Indonesia, Penerbit Balai Pustaka, Jakarta, 1992.

Ranupandojo, Heidjrachman dan Suad Husnan, Manajemen Personalia, Edisi Keempat, Penerbit BPFE, Yogyakarta, 1992.

Siswanto, Bedjo, Manajemen Tenaga Kerja Ancaman dalam Pendayagunaan dan Pengembangan Unsur Tenaga Kerja, Penerbit Airlangga, Jakarta, 1987.

Sudjana, Nana, Dasar-Dasar Proses Belajar Mengajar, Sinar Baru, Bandung 1988.

Suryadi, Ace, Membuat Siswa Aktif Belajar, Bina Cipta, Bandung, 1993.

Tim penyusun, Profesionalisasi Jabatan Guru, Direktorat Jenderal Pendidikan Tinggi Jakarta, 
